UDC 342.5

DOI https://doi.org/10.32837/pyuv.v1i3(28).315

\author{
A. A. Nastuyk \\ Candidate of Juridical Sciences, \\ Associate Professor at the Department of Constitutional, \\ Administrative and Commercial Law \\ of Academy of Labor, Social Relations and Tourism
}

\title{
INFLUENCE OF USURIOUS RELATIONS ON THE DEVELOPMENT OF KIEVAN RUS
}

Today, there is a need for a deeper study of this phenomenon with the development of the credit system of Ukraine. In Soviet times, the study of this issue was complicated due to ideological obstacles.

Blind borrowing of legislation to regulate credit relations from abroad with no taking into account national peculiarities will lead to the formation of legal nihilism. Therefore, there is a need to study the origin and development of usury in Kievan Rus, as the initial stage of their formation.

No market economy in the world can actively develop without a developed credit system. An additional finances engagement under commitments is one of the necessary factors for economic development. The funds are borrowed by both individuals and legal entities. Even the state borrows money from other states or international organizations. Just as Ukraine rejected the market economy before 1991, the crediting is the new one for it and, for some of our citizens, it is a shameful one. We need to change this situation by changing the financial culture of the population.

To do this, it is necessary to investigate the first manifestations of the emergence of credit relations, which were called 'moneylanding' in the Kievan Rus.

The state of the study of the historical and legal aspects of the credit system in Ukraine is not sufficient. In the Soviet Union, in view of the censorship barriers the usury was viewed from ideological point of view. Such prominent researchers of this period as B.D. Grekov, B.O. Rybakov, P.P. Tolochko and other Soviet scientists considered the usury as the way of exploiting the people by the rich and saw a class confrontation in it. We believe that today we need to pay more attention to the study of this issue, excluding the class approach.

The purpose of our work is to investigate the development of usury relations in Kievan Rus. To do this, we will analyze historical events related to borrowing money including princely power, the state of legal regulation of usury relations, and its impact on the state policy of Kievan Rus.

From the Russo-Byzantine treaties we can see that trade relations were actively developing in Kievan Rus [1, p. 64-65, 6-10, 30-35]. The search for new markets for their goods indicated an increase in export trade. The cities were transformed from tribal fortresses into administrative shopping centers. In turn, it indicates the active development of domestic trade.

The rapid economical development of the medieval city needed opportunities to lend to the undertakings of the Russes. This led to the emergence of usurious relations. We learn about usury in Kievan Rus from the uprising in Kiev that led to the legal regulation of these relations.

The uprising began shortly after the death of Grand Duke Svyatopolk Igorevich in 1113. The victims of the insurgency were the Jews, who were killed and plundered by the people of Kiev. The reason for such outrages was the fact that the Jews received too much power and wealth during the rule of Svyatopolk. They overthrew merchants and artisans, taking away their craft from Christians. They were also accused of deceiving Christians in their faith. But first of all, we are interested in the economic aspects of this uprising. To solve this problem, the Kiev boyars treated to Vladimir Monomakh, who assembled a princely congress in Vydubychi. The congress decision was to deport all Jews together with their property from Kievan Rus [2, p. 146-147].

The Russes believed that it was the Jews who used the money to ravage the people of Kiev. The fact that the Jews did usury in Kievan Rus is not surprising, because the church condemned usurious relations, believing that a Christian has no right to borrow interest from another Christian. That is why it was the Jews who were engaged in this business, since they were Jewish, so they could give money at interest to Christians.

ButMonomakhdidnotprohibitusuryexpelling the Jews, but only facilitated the conditions for debt collection. In turn, it means that the Russes were also engaged in usury. Consequently, the church was unable to influence the princely power by prohibiting usury.

Issues of usury were regulated by the Russ truth [1, p. 126-128].

Art. 47 regulated the issue of debt repayment. The witnesses who had to confirm the borrowing of money play an important role in the return of money. In addition, the money should be returned with a supplement of three hryvnia.

Art. 48 regulated the lending of money to merchants for wholesale and retail trade. This case regulates the case when for some reason there were no witnesses in the contract. In this regard, the borrower proves the validity of the contract by his own oath. 
Art. 49 settled the issue of letting the property to be preserved and returned. This article describes cases where a dispute arises as to the amount of property that has been leased. The dispute is also resolved by oath.

Art. 50 contained provisions on interest rates on usurious transactions.

Subsequent Article 51 regulated the monthly interest rate and Article 52 concerned debt repayment.

Art. 53 regulated interest rates already under the charter of Vladimir Vsevolodovich (Monomakh).

Art. 54 and 55 also solved the issue of debt repayment [1, p. 127-128].

Rybakov B.A. researched this issue and so interpreted the regulation of usury relations. If one borrowed six hryvnias, he would have to pay three percent of the hryvnia every year. Therefore, he had to pay fifty percent of the loan per each year until he paid the debt. And if the debtor could not pay off the debt besides the interest, then the terms of payment of the interest until repayment of the debt were not limited.

Due to the amendments to the legislation, Vladimir Monomakh set a deadline. For example, six hryvnia debt was paid over three years at three hryvnia percent. During this time, the debtor had to pay an additional 3 hryvnias, ie 6 hryvnia of debt and 3 hryvnias of "growth". This innovation protected the debtors from "eternal debt" [3. P. 195].

So, it seems that Monomakh has decided to protect the underprivileged population of Kyiv from moneylenders. This can be interpreted as the populist actions of Volodymyr Monomakh, who followed these steps to gain support in Kyiv among its debt-stricken residents and thus to end the uprising.

But this situation can be considered in another way. To do this, we need to find out why Yaropolk allowed the Jews to lead and give them trade privileges? What happened during this period in Kievan Rus? It is possible to analyze the events that preceded the uprising and give us an answer to our question.

As soon as the Grand Duke of Svyatopolk began to rule in 1093, the Polovtsian invasion took place. It ended with the defeat of Svyatopolk Izyaslavovich, Vladimir Vsevolodovich and the death of his brother Rostislav. It should be noted that Svyatopolk was broken twice this year. The Polovtsians plundered many villages, reached almost Kiev and took Torzhok. Thus, in Kiev land, the prince lost the battle twice in one year, which led to the destruction of the surrounding villages and the capture of Torzhok [4, p. 6-7].

In 1094, Oleg Svyatoslavovich expelled Vladimir from Chernihiv, and his allies Polovtsians destroyed the Chernihiv land. In the same year locusts came to the $\mathrm{n}$ land and ate crops, which was not yet on such scales, according to annals [5, p. 182-183; 2, p. 107].

In 1095 the Polovtsian khans Itlar and Kitan came to Pereyaslav to demand a tribute from Vladimir.
As a result of the negotiations, the Russes cunningly killed Itlar and Kiyat at the suggestion of Slavat, who was a representative of Prince Svyatopolk. Then Vladimir and Svyatopolk defeated the Polovtsians. This year the Korsuns attacked and robbed Russian ships. Therefore, the Russes organized a hike to Korsun and won. At the same time, there was an attack by the Polovtsians on Yuriev, whose inhabitants fled to Kiev. And the Polovtsians devastated everything there [4, p. 8-9].

Let's look at the chronology of events by years.

1096. Svyatopolk and Vladimir's war against Oleg Svyatoslavovich. This conflict has led to the destruction of many cities and villages. Izyaslav Vladimirovich was killed. Prince Bonak of Polovtsians came and ruined the outskirts of Kiev. Even Pecherskiy Monastery was burned down [2, p. 110-112].

1097. Due to Vasylko's blindness, Svyatopolk becomes in dispute with Vladimir Monomakh, David and Oleg Svyatoslavovich [4, p. 12-14].

1098. Svyatopolk is at war with David for Cherven Cities. This year Svyatopolk also fought with Rostislavoviches, where he was defeated.

1099. The Russes defeated the Hungarians thanks to the support of the Polovtsians.

1100. An earthquake occurred in Kievan Rus [2, p.129-135].

1101. Yaroslav Yaropolchych who was Izyaslav's grandson, fought with his uncle Svyatopolk.

1103. There was a great march of Russes led by Svyatopolk on Polovtsians. In this war, the Polovtsians lost twenty princes. The same year there was a war with Mordva. Again locusts arrived in Russia [4, p.19-20], [2, p. 137-139].

1104. The troops of Svyatopolk go to Glib Vseslavovich the Minsk [2, p. 139].

In the winter of 1105 Bonak, Prince of Polovtsians, came to Rus. In 1106 it was defeated by the troops of Svyatopolk.

1107 Bonak came to Rus again. But Russes defeated him again.

1108. Floods occurred in the Dnieper, Desna and Pripyat.

$1109,1110,1111$. There were hikes of the Russians to the Polovtsians. As a result of the military campaign, the Polovtsians suffered considerable losses [2, p. 140-142], [6, p. 1-2].

1112. The son of Svyatopolk marched the troops against the Yotvingians [7, p. 4].

Thus, all the rule of Svyatopolk consisted of constant wars with their relatives, repelling the raids of the Polovtsians and organizing their actions of revenge. In addition, the wars with neighbors continued. During this period, besides the military losses, Rus suffered from natural disasters that were detrimental to its economy. In fact, every year the princely administration was forced to address important issues, such as wars or the threat of fam- 
ine from the destruction of fields by Polovtsians and locusts. It is clear that this required huge financial resources. And, probably, Svyatopolk borrowed money from the Jews, which is why he brought them closer to himself and gave them preferences to settle with them or delay the repayment period.

So, the prince of Kiev got into debt. His death was not a reason for them not to be paid by his successor. That is why Vladimir Monomakh was probably interested in holding Ostracism against them. In fact, the expulsion of Jews from Rus is Vladimir Monomakh's refusal to pay them debts. He simply drove them outside the state.

Quite interesting circumstances about lending money by Russes to their prince took place during the struggle for the princely table of Yaroslav and Svyatopolk Vladimirovich.

Yaroslav expelled his brother Svyatopolk from Kiev in 1016. The victory was not definitive and in 1018 Svyatopolk Vladimirovich, having received support from his father-in-law Boleslaw together with the Poles defeated Yaroslav. After the defeat, Yaroslav retreated to Novgorod, which supported the prince in his struggle for power, and decided to flee to the Scandinavians.

The Novgorod people, fearing reprisals from Svyatopolk because they supported Yaroslav, decided to fight further. To this end, they damaged the ships on which the prince wanted to flee and forbade him to flee. Novgorod people demanded the continuation of the war from Yaroslav. The prince was motivated by the inability to wage war without his means. The Novgorod people themselves raised funds from different segments of the Novgorod population and hired Scandinavians [4, p. 62].

According to Tatishchev, in 1018 the following funds were raised. From the peasant were raised four kunas, from the headman - 5 hryvnias, from the boyars -18 hryvnias [2, p. 71].

According to the Laurentian Chronicle, 4 kunas were collected from the lord in 1018, 10 hryvnias from the headman and 18 hryvnias - from boyars [8, p. 62].

Let's find out the hryvnia value course by converting it into kunas, nogats, rezans, veveritses.

The hryvnia, consisting of an appropriate number of coins, was called the hryvnia kun. The hryvnia kun consisted of ( $50 \mathrm{~g}$ silver), it equals 25 kunas $=$ 20 nogats $=50$ rezans $=150$ veveritses. The hryvnia of silver had a weight of 204 grams and was equal to almost four hryvnias kun [9, p. 52-53].

In our study, we aim to find out whether this money was a gift, an interest-free loan, or yet an interest-bearing loan. We have reason to believe that not all the money was donated to the prince, but a loan was made in his favor. According to the Laurentian Chronicle, it is not stated that the prince was given a loan, since it has no information that the prince re- paid this money. This indicates that the money was donated to the prince. But Tatishchev has data on their return.

In 1019, Yaroslav went to Kiev and took his parents table and became to reward soldiers after winning. He gave the chief elders 50 hryvnias to the chief elders, 1 hryvna to simple soldiers, and also gifted Novgorod people [2, p. 72].

We believe that giving the prince money is not a gift, but a return of debt. But not only Tatishchev pointed it out, there are also the chronicles did.

The Nikon Chronicle indicates the following information. In 1020 Yaroslav gave to the elders 10 hryvnas, to smerds - 2 hryvnas, to Novgorod people - 10 hryvnas [10, p. 77].

According to the information received, the prince took the money from Novgorod people, and later gave it. So it's not a gift, it's a loan. Now let's find out if it was an interest-bearing or interest-free loan.

It is probable that the peasants indicated by Tatishchev are smerds, which according to him, received 1 hryvna. So, they gave 4 kunas and received 1 hryvnia ( 25 kunas). The prince knew 6.25 times more than he took. But the Nikonov Chronicle indicates that the smerds received 2 hryvnas (50) kunas, which is 12.5 times more. Why are two different values given?

The answer is simple, it's a year of giving out money. In the first case, the money was given a year later, namely in 1019 [2, C. 72]. And in the second case, two years after the loan, in 1020 [10, p. 77]. So, if the percentage was the same, then you should double the amount: $6.25+6.25=12.5$. So we got the amount we needed.

We assume that Yaroslav borrowed money but could not give it in one year. Therefore, in 1019 he returned one hryvnia for four kunas, and in the second year in 1020 for the same four kunas he returned two hryvnas. In one year the amount increased from the borrowed 6.25 times. We consider the war as the reason of the prince's inability to pay the debt. As a result of the war Svyatopolk took away all the money that was in the treasury, while escaping [8, p. 62-63]. Therefore, Yaroslav needed time to fill up the treasury and repay the debt.

According to the Chronicle of Nikon, the prince took ten hrivnas from the elders and returned them ten hryvnas. So we have an interest-free loan. And according to Tatishchev, the elders were given 5 hryvnas and received 50 hryvnas, which indicates that they receive ten times more profit than they borrowed. But Tatishchev pointed out the chief elders. And these may not be exactly the elders who gave 5 hryvnas. As for Novgorod people and boyars, it does not indicate how much Novgorod people paid and how much they returned to the boyars [10, p. 76-77], [2, p. 71-72]. Therefore, we do not take them into account in our study. We conclude 
that there was an interest loan of four kunas and an interest loan of 10 hrynvas.

Why were the elders not given an interest loan? They may have been one of those who advocated the continuation of the war and initiated this process together with the boyars, and therefore did not have the opportunity to take a percentage, since they were interested in the victory of Prince Yaroslav. And the boyars in general could give the prince their money, as the most interested and wealthy population.

Let's judge ourselves: Svyatopolk came to Novgorod. Who would suffer the most? The elders and boyars who would be released would suffer by putting ones that are more faithful. In general, they could be killed to take their property. It follows the principle of justice, which is expressed in the one who suffers more, pays more.

This example shows that the prince could borrow money from the inhabitants of his land. But is this case isolated? Who else could the Prince borrow money from? We find interesting the events of the confrontation between Vladimir Svyatoslavovich and his brother Yaropolk Svyatoslavovich.

In 972, the Russian prince Svyatopolk was killed by Khan Kurya [11, p. 27]. Rus remained with his three sons. Yaropolk, the eldest son, started reigning by his father in Kyiv. Oleg was sent to reign in the land of Drevlyan. And bastard Vladimir was sent to Novgorod.

After the death of his father, as early as 975 , a conflict arose between his legitimate sons. The reason for the confrontation was the murder of Lut, son of Sveneld by Prince of Drevlian Oleg. The war ended with the death of Oleg, who died in 977 [12, p. 22]. After Oleg's death, Vladimir was scared for his life and fled to the Varangians. Yaropolk sent his squadron to Novgorod [13, p. 34].

In 980, Vladimir returned to Kievan Rus with the Varangians and expelled Yaronpolk from the town of Novgorod and declared war on him. Vladimir stated that the cause of the war was his revenge to Yaropolk for the death of his brother Oleg and for his own insults [12, p. 22].

When Vladimir came under the walls of Kiev with his numerous army, the faithful people of the Grand Duke advised Yaropolk not to demand his army to be idle outside the city walls, but to go out into the field and open battle to defeat Vladimir. But the traitor Blut from the immediate vicinity of Yaropolk convinced the prince to sit behind the walls [2, p. 43].

Then Blut began to persuade Yaropolk that the people of Kiev wanted to betray him and that he should flee the city [11, p. 28].

According to chronicles, Yaropolk succumbed to the provocation of Blut and left the city after retreating to the town of Rodnya. The people of Kiev, who left without a prince, let Vladimir come into the city. In Rodnya, at the negotiations which Blut of- fered to conduct, on the orders of Vladimir Svyatoslavovich, two Varangians were treacherously killed Prince Yaropolk [12, p. 22; 14, p. 187-188].

This story is quite amazing. The exile prince recruits the Varangians, gathers troops and captures Polotsk and Kiev, defeating Rogwold and Yaropolk. Particularly interesting is the situation in Kiev. The immediate surroundings betray Yaropolk. We don't think Blut was alone. Traitors persuade the prince not to gather an army against Vladimir, showing complete passivity in the attack of the enemy. Thanks to their activities, the army sieges and does not go out to fight in the field. Later, the prince was taken out of Kiev. And as soon as the prince leaves it, the Kiev people let the troops of Vladimir come into the city, which is like conspiracy and betrayal. Prince Yaropolk's treacherous murder in the negotiations is the logical end of this story.

War is not only the confrontation of warriors, but also the confrontation of money. Where did Vladimir get the money to hire Varangians and collect troops? After all, for this purpose large funds were needed to confront Rogwald and Yaropolk. The campaign against Kyiv was won by the fifth column, I mean by treason. What guided chief traitor Blut and his associates? Perhaps the situation with the new prince. But it is clear from the chronicles that Blut enjoyed the incredible confidence of Yaropolk. Analyze Blut's actions and the prince's reaction. Blut advises the prince not to gather troops. He argues that his troops will move to the side of the Grand Duke themselves, since Vladimir does not seem to be using their support. And what really happened? The enemy surrounds Kiev and does not intend to move to the side of Yaropolk. Thus, the advice of Blut has had catastrophic consequences. And what did the prince punish him for, or possibly remove him from? No, he listened to his next "genius" advice, namely: to sit in Kiev on the walls without giving a general fight to Vladimir. This, in turn, led to the loss of authority in Yaropolk and the belief in his victory due to inaction. Perhaps the prince would now at least remove the advisor? No, he followed his advice: to leave the capital. It worthed Kiev to Yaropolk. Maybe after that he ordered to execute Blut, or at least drive away this advisor from himself? No, he obeyed him and went to the negotiations. And it already worthed the prince his life.

From this we can conclude that Blut enjoyed incredible, even irrational trust in Prince Yaropolk. So, what exactly has Blut betrayed his prince in the hope that he would have a similar place to Vladimir? But who will trust a man who has so treacherously betrayed his prince in their right mind?

Perhaps Blut betrayed the prince because he did not believe in Yaropolk's victory in the confrontation with Vladimir. But if Blut did not do the blasting, then Yaropolk would have more chances to emerge 
victorious than Vladimir. Only the actions of Blut enabled Vladimir to emerge victorious from this war.

Why did Blut betray? We think he was bribed. That is, Vladimir bribed his opponents and they betrayed their prince, but it is clear that the money for this had to be very large. One thing is clear from it. Vladimir had incredible financial resources and these resources could not be his own ones. In general, no land could allocate such money. After all, the richest was Kiev, where Yaropolk also was. Who did Vladimir borrow this money from?

The answer to this question can be found in the work of Nastyuk AA He assumed in his studies that it was pagan priests of the Magi who sponsored Prince Vladimir. The argument is that Yaropolk was probably a Christian, since he was raised by a Christian grandmother, Princess Olga. It is clear that since the reign of Olga the Christianity has become increasingly important in Kievan Rus. The defeat and death of the pagan Svyatoslav continued to weaken the position of the pagans. That's why they borrowed money from Vladimir to fight Christianity. As soon as Vladimir took power in Rus, he began to carry out religious pagan reform. This reform led to a struggle among the Gentiles themselves, as only a portion of the pagan gods were favored. And later the prince Christianized the country. And he began to persecute the pagans of the Magi [15, p. 34-37]. Perhaps the reason for the Christianization of was the reluctance to repay the prince's debts to the pagans. From this it follows that the princes borrowed money and in religious organizations.

Historically, money has been borrowed by both ordinary powers and princes. In order to fight for power, money was needed, and the princes borrowed this money from those who were ready to give it. But even when the prince came to power and took control in his own hands, it was not a guarantee of his financial stability. The constant attacks of nomads and the destruction of large territories, the war with foreign powers, internecine strife, and even the common locust, devastated princely resources with incredible power. In order to stabilize their financial situation, the princes were forced to borrow money from those who could provide them: religious organizations, land assembly meetings, foreign minorities. Money was taken by both princes and simple movements, committing themselves to their return as a percentage. Useless relations were so widespread in Kievan Rus that they were governed by Russian truth.

Debtors may not always be able to pay their creditors money, so sometimes they go for the trick. It could even lead to a change in religion to outlaw the religious organization to which the money was to be donated. The goals of the uprising were for one purpose: to expel creditors from the country so that they would not be paid anything. Incidentally, the same was true in France, when King Philip VI of the Valois Dynasty expelled the Lombards from the country and refused to pay them back.

People's dissatisfaction with moneylenders led to changes in the regulation of usurious relations in the $\mathrm{n}$ truth. These changes have more rigorously controlled by the state these relations, not allowing the moneylenders to abuse their position and receive extra profits. Cash limits were set - how much could be taken off the debtor. Extraordinary majestic circumstances were introduced that could enable the debtor to repay the debt gradually.

In the paper, we calculated the interest rates paid by Prince Yaroslav when borrowing from Novgorod.

In our study, we pointed out that not only the common people but even the Grand Duke could have a problem with debt repayment. And that the authorities, too, could cover themselves with religious reforms, the support of ordinary people of commerce from strangers to usurers, aiming not so much to help the people as not to pay their debts. As the case with the Novgorod council shows, the princes paid the debts only to those who needed support.

Thus, in Rus actively developed usurious relations. Even the princes borrowed as a percentage of the money. The activity of development of usurious relations is confirmed by the fact that they were regulated by the Russian truth. But in 1113 many borrowers collapsed due to harsh conditions, which led to the uprising. It cannot be said that Jews were the main problem of usury. After all, even when they were expelled from Rus, the usurious relations did not end. Only the debt relief has softened. This, in turn, indicates that the economy of Russia was so developed that a complete cessation of usury operations was no longer possible without grave consequences for the economy of the state. The uprising is more reminiscent of trying to ruin competitors than ethnic conflict.

\section{References}

1. Yushkov S.V. Monuments of Russian Law. Moscow : Gosyurizdat, 1952. 287p.

2. Tatishchev V.N. The Russian History. Moscow : Ermak, 2005. Vol. 2. 735 p.

3. Rybakov B.A. The World of History. Moscow : Young Guard, 1984. $351 \mathrm{p}$.

4. The complete collection of Russian chronicles. Chronicle of the Resurrection List. St. Petersburg : Typography of Edward Work, 1856. T. 7. 346 p.

5. The Complete Collection of Russian Chronicles. Chronicle collection, called the Tver Chronicle. St. Petersburg : Typography of Leonid Demis, 1863. Vol. 15. 305 p.

6. The Complete Collection of Russian Chronicles. Ipatiev Chronicle. St. Petersburg : Typography of Edward Labor, 1843. Vol. 2. 378 p.

7. The Complete Collection of Russian Chronicles. Novgorod Chronicles. St. Petersburg : Typography of Edward Work, 1841. T. 3. 307 p.

8. Full Collection of Russian Chronicles. St. Lawrence and Trinity Chronicles. St. Petersburg : Typography of Edward Prats, 1846. Vol. 1. 267 p. 
9. Kovnir V.N. Economic history of Russia. Part 2 From ancient times to 1017: textbook for air defense / VN. Cov. 2-ed., Ed. And M. Publishing House Yurayt, 2018. $252 \mathrm{p}$.

10. The Complete Collection of Russian Chronicles. Patriarchal or Nikon Chronicle. St. Petersburg: Typography of Edward Prats, 1862. T. 9. 256 p.

11. The Complete Collection of Russian Chronicles. Typographical Chronicle. St. Petersburg : 2nd State Typography. Galley 1, 1921. T. 24. 272 p.

12. The Complete Collection of Russian Chronicles. Ustyuzh and Vologda Chronicles of the XVI - XVIII centuries. Leningrad : Science. 1982. T. 38. 228 p.

13. Karamzin N.M. On the History of the State of Russia. Moscow : Enlightenment, 1990. 384 p.

14. Karamzin N.M. History of the State of. The book is the first. Rostov-on-Don : Rostov Book Publishing House, $1989.603 \mathrm{p}$.

15. Nastyuk AA The reasons for the christening of Kievan Rus / A.A. Nastyuk. Bulletin of the Academy of Labor and Social Relations of the Federation of Trade Unions of Ukraine. Series: Law and Public Administration. Kyiv : "STEEL", 2013. № 11. P. 33-39.

\section{Summary}

Nastuyk A. A. Influence of usurious relations on the development of Kievan Rus. - Article.

The purpose of our work is to study usury relations and their impact on the development of Kievan Rus.

The source legal basis shows that in Kievan Rus the usury was governed by princely legislation. Russian-Byzantine treaties emphasize the interest of the princely power in stable trade relations. In our opinion, namely, the stimulation and support from the state to the traders explain the intensive development of trade relations in the state, which, in turn, develop usurious relations, since the creation of a credit system is a necessary element of increasing trade operations.

We have analyzed the chronicles and found that the foreigners (Jews), indigenous peoples (Russes), religious organizations and councils were the borrowers. Our study found that not only ordinary people, but also princely power were credited.

In the paper, we considered the reasons for ensuring the legal regulation of usurious relations through the introduction of new articles in the Russian truth during the reign of Vladimir Monomakh in Kiev.

During the study, we concluded that the subjects of usurious relations were not only ordinary people and boyars who took money out at interest, but also princes did.

We found that the princes borrowed money from religious organizations, congregations, and Jews. We found out that owing to debts, the princes were forced to make concessions to creditors. This led to a change of policy in the state. Our study found that the princes did not always want to be responsible for their debt obligations. The princes' reluctance to repay debts prompted them to break and violate credit conditions, even to amend legislation.

The victims of usurious relations were not only the princes but also the people of Kiev. The uprising of 1113 was the result of harsh conditions for repayment of debt interest rates. The expulsion of the Jews is a clear indication that the authorities in Kievan Rus fought not with usury, but with foreign residents who could interfere with the internal affairs of Kievan Rus through their debts. The influence of the prince administration on the personal system in the interests of his social group caused a revolt, as it happened after the death of Svyatopolk II. If the purpose of power was to fight against usury, in Rus- sian truth it would be forbidden. After the expulsion of the Jews, the authorities softened the conditions for borrowing money. In turn, it indicates that not only Jews but also Russes were engaged in usury. Thus, the expulsion of the Jews was a factor in the competition for usurious cash flows.

We concluded that the level of economic development of Kievan Rus was closely linked to usurious relations.

Key words: Kievan Rus, moneylenders, Council, kunas, nogats, rezanas, maguses.

\section{Анотація}

Настюк $А$. А. Вплив лихварських відносин на розвиток Київської Русі. - Стаття.

Метою нашої роботи є дослідження лихварських відносин та їх вплив на розвиток Київської Русі.

Джерельна законодавча база вказує на те, що лихварство в Київській Русі регулювалось княжим законодавством. Русько-візантійські договори акцентують увагу на зацікавленості князівської влади у стабільних торгівельних зв'язках. Саме стимуляція та підтримка з боку держави торгівців, на нашу думку, i пояснює інтенсивний розвиток торгівельних відносин у державі, які своєю чергою розвивають лихварські відносини, оскільки створення системи кредитуваньє необхідним елементом збільшення торгівельних операцій.

Ми проаналізували літописні джерела і виявили, що позичальниками коштів були іноземці (євреї), корінні жителі (руси), релігійні організації та віче. Наше дослідження виявило те, що кредитувалися не тільки прості руси, але й князівська влада.

У роботі ми розглянули причини забезпечення правової регуляції лихварських відносин через внесення нових статтей у Руську правду під час правління в Києві Володимира Мономаха.

Під час дослідження ми дійшли думки, що суб'єктами лихварських відносин були не тільки прості руси та бояри, які брали гроші під відсоток, але й князі.

Ми виявили, що князі позичали гроші в релігійних організаціях, вічевих зібраннях та у євреїв. Ми з'ясували, що через борги князі були змушені йти на поступки кредиторам. Це призводило до зміни політики в державі. Наше дослідження виявило, що не завжди князі хотіли нести відповідальність щодо своїх боргових зобов'язань. Небажання князів віддавати борги спонукало їх до розірвання та порушення умов кредитування, навіть до внесення змін у законодавство.

Жертвами лихварських відносин ставали не тільки князі але також і кияни. Повстання 1113 року стало результатом жорстких умов щодо погашення процентних ставок боргу. Вигнання євреїв є яскравим свідченням того, що влада в Київській Русі боролася не 3 лихварством, а з іноземними резидентами, які завдяки боргам могли втручатись у внутрішні справи Київської Русі. Вплив на кадрову систему адміністрації князя в інтересах своєї соціальної групи спричиняв бунт, як це сталося по смерті Святополка II. Якби ціллю влади була боротьба із лихварством, то в Руській правді воно було б заборонене. Після вигнання євреїв влада пом'якшила умови отримання в борг грошей. Це своєю чергою вказує на те, що лихварством займались не тільки євреї, але й і руси. Отже, вигнання євреїв було фактором конкурентної боротьби за лихварські грошові потоки.

Ми дійшли думки, що рівень економічного розвитку Київської Русі був тісно пов'язаний з лихварськими відносинами.

Ключові слова: Київська Русь, лихварі, віче, куни, ногати, резани, волхви. 